54 Harter S. Self and identity development. In At the Threshold: The Developing Adolescent (eds S Feldman, G Elliott ): 352-87. Harvard University Press, 1990.

55 Pompili M, Lester D, Forte A, Seretti ME, Erbuto D, Lamis DA, et al. Bisexuality and suicide: a systematic review of the current literature. J Sex Med 2014; 11: 1903-13.

56 Machado S. The poetics of parent-son encounters following negative parental reactions to the disclosure of gay identity. J Humanist Psychol 2014 55: 30-52.

57 Meyer IH. Minority stress and mental health in gay men. $J$ Health Soc Behav 1995; 36: 38.

58 Meyer I, Dean L. Internalized homophobia, intimacy and sexual behaviour among gay and bisexual men. In Stigma and Sexual Orientation (ed. G Herek) 160-86. Sage, 1998.

59 Hammelman T. Gay and lesbian youth. contributing factors to serious attempts or considerations of suicide. J Gay Lesbian Psychother 1993; 2 77-89.
60 Armesto J, Weisman A. Attributions and emotional reactions to the identity disclosure ('coming out') of a homosexual child. Fam Process 2001; 40: 145-61.

61 Ryan $C$, Huebner $D$, Diaz $R$, Sanchez J. Family rejection as a predictor of negative health outcomes in White and Latino lesbian, gay, and bisexua young adults. Pediatrics 2009; 123: 346-52.

62 Gecas V, Libby R. Sexual behavior as symbolic interaction. J Sex Res 1976 12: $33-49$.

63 American Psychological Association. The Guidelines for Psychological Practice with Lesbian, Gay and Bisexual Clients. APA, 2011

64 O'Connor D, Green S, Higgins JPT. Defining the review question and developing criteria for including studies. In Cochrane Handbook for Systematic Reviews of Interventions (eds J Higgins, S Green): ch 5. Cochrane Collaboration, 2008.

65 Sterne J, Sutton A, Ioannidis J, Terrin N, Jones D, Lau J, et al. Recommendations for examining and interpreting funnel plot asymmetry in meta-analyses of randomised controlled trials. BMJ 2011; 342: d4002.

\title{
reflection
}

\section{The Psychopathology of Everyday Life, Sigmund Freud}

\author{
Jeremy Holmes
}

Joyous is not a word normally associated with Freud despite being the true meaning of his name. But The Psychopathology of Everyday Life fully deserves the epithet: a glorious collection of anecdotes, spoonerisms, lacunae, 'speech blunders' and odd actions - revealing, he argues, the cauldron of repressed feelings lurking below consciousness.

The book belongs to Freud's middle period, while still a passionate clinician reveling in free-associationism, and relatively unencumbered by meta-psychology. Written in 1901, published in 1904, it was first translated into English by Brill in 1914 'Fehlleistungen' was changed by Strachey from Brill's 'faulty action' to the pseudo-medical 'parapraxis'. The 'Freudian slip', with its double entendre of a revealing/concealing female undergarment, appeared in 1959

The Psychopathology of Everyday Life reveals Freud at his most scintillating. Many examples come from his own life, professiona and personal. We learn of his marital tiffs; his daughter's life-threatening illness; sexual attraction to a younger woman; omitting to pay bills and losing his keys; rivalry with colleagues; and, despite his famed photographic memory, forgetting the name of a famous Renaissance painter, Signorelli. He touchingly exposes his professional failures: an analysand's suicide; patients he mis-diagnosed with 'hysteria' who had a brain tumour or multiple sclerosis.

Freud's mission is threefold: (1) to illustrate the continuity between normality and pathology, counteracting the prevalent view of mental illness as manifestation of 'degeneracy'; (2) following The Interpretation of Dreams, to show that 'dream-life' continues during the day: (3) to convince that 'faulty action' - including speech - is 'motivated' by warded-off affective states: 'forgetting in all cases is proved to be founded on a motive of displeasure'. It is not the feelings in themselves that are 'displeasureable'. Sexuality, and the desire for fame and recognition, are no less unconsciously 'motivating' than resentment, shame and disappointment. Displeasure lies in the anxiety associated with such feelings. Parapraxis arises out of what we now see as 'affect phobia'.

But was Freud right? True, scientific curiosity does not shy away from the everyday. Darwin learned as much from the worms in his Down House garden as from Galapagos finches. Freud argues for everyday material's 'admission' to science, subject to 'stricter methods of verification'. He is in awe of 'the great Darwin's' practice of noting examples which ran counter to his theories, fearing that wish-fulfillment would otherwise suppress them. Sadly, Freud fails to apply these strictures to himself. There are few if any black swans in The Psychopathology of Everyday Life; psychic determinism rules.

We know now that many slips are unmotivated, flowing from 'banalisation', verbal typos and ingrained habit. But parapraxes are also undeniable. What primary school child has, to their horror, not called mistakenly their teacher 'Mum'? Male subjects given verbal tasks by scantily clad female psychologists tend to produce unwitting sexual innuendos. Avoidantly attached individuals have high cortisol levels, suggesting suppressed attachment needs; when subject to 'cognitive load', for instance in Stroop tests, the need for security parapraxically reveals itself.

A century on, Freud's ode to psychoanalytic joy has lost none of its freshness and relevance: essential reading for all would-be wise and witty psychiatrists. 